\title{
Sistem Informasi Manajemen Pemesanan Dan Penjualan Pada UNDIP Distro
}

\author{
Mohammad Dwi $\mathrm{C}^{1)}$, Kodrat Iman Satoto ${ }^{2)}$, Rinta Kridalukmana ${ }^{2)}$ \\ Jurusan Sistem Komputer, Fakultas Teknik, Universitas Diponegoro \\ Jl. Prof. Sudharto, Tembalang, Semarang, Indonesia \\ Email: undipdistro@gmail.com
}

\begin{abstract}
At present time, information technology facilitates business very well. The eases provided by technology will attract many consumers. However, a middle level company such as UNDIP Distro is rarely found providing neither the ease of shopping or online ordering service. Therefore, web based system is needed by UNDIP Distro company in order to facilitate the owner and the admin to manage the sale, service, and marketing and the customer's shopping

Sistem Informasi Manajemen Penjualan dan Pemasaran UNDIP Distro is a web based application made using PHP program language in scope of Framework Code Igniter and basic data of MySQL. The development method used is waterfall method. Information system modeling in application plan was built using UML modeling.

The result of the application plan is a web based application that can manage data in UNDIP Distro such as products, orders, and members data.
\end{abstract}

Keywords: web base information system, PHP, framework Code Igniter, MySQL, UML

\section{PENDAhUluan}

engolahan data transaksi transaksi penjualan dan

P mempermudah perusahaan dalam memanajemen data produk serta data pemesanan merupakan hal pokok yang melandasi dibuatnya sistem informasi pada UNDIP Distro ini, Sistem Informasi ini menawarkan solusi untuk mengatasi permasalahan yang ada. Keuntungan selanjutnya adalah bagi pihak perusahaan, dengan diterapkembangkannya sistem ini pengelolaan data lebih mudah dilakukan, baik itu data produk, data pemesanan dan data member, selain itu dengan Sistem Informasi ini pemasaran bisa lebih luas lagi untuk menjaring konsumen yang lebih banyak.

\section{LANDASAN TEORI}

\section{A. Sistem Informasi}

Sistem informasi dapat didefinisikan sebagai berikut : a. Suatu sistem yang dibuat oleh manusia yang terdiri dari komponen-komponen dalam organisasi untuk mencapai suatu tujuan yaitu menyajikan informasi. b. Sekumpulan prosedur organisasi yang pada saat dilaksanakan akan memberikan informasi bagi pengambil keputusan dan atau untuk mengendalikan organisasi.

c. Suatu sistem di dalam suatu organisasi yang mempertemukan kebutuhan pengolahan transaksi, mendukung operasi, bersifat manajerial dan kegiatan strategi dari suatu organisasi dan menyediakan pihak luar tertentu dengan laporan-laporan yang diperlukan.

Organisasi menggunakan sistem informasi untuk mengolah transaksi-transaksi, mengurangi biaya dan menghasilkan pendapatan sebagai salah satu produk atau pelayanan mereka. Bank menggunakan sistem informasi untuk mengolah cek-cek nasabah dan membuat berbagai laporan rekening koran dan transaksi yang terjadi. Perusahaan menggunakan sistem informasi untuk mempertahankan persediaan pada tingkat paling rendah agar konsisten dengan jenis barang yang tersedia.

Sebagian sistem informasi berlandaskan komputer terdapat di dalam suatu organisasi dalam berbagai jenis. Anggota organisasi adalah pemakai informasi yang dihasilkan sistem tersebut termasuk manajer yang bertanggung atas pengalokasian sumber daya untuk pengembangan dan pengoperasian perusahaan. (Bin Ladjamudin, Al-Bahra, 2005)

\section{B. Software Development Life Cycle}

SDLC atau Software Development Life Cycle atau sering disebut juga System Development Life Cycle adalah proses mengembangkan atau mengubah suatu sistem perangkat lunak dengan menggunakan modelmodel dan metodologi yang digunakan orang untuk mengembangkan sistem-sistem perangkat lunak sebelumnya (berdasarkan best practice atau cara-cara yang sudah teruji baik).

Tahapan-tahapan yang ada pada SDLC secara global adalah sebagai berikut :

a. Inisiasi (initiation)

b. Pengembangan konsep sistem (system concept development)

c. Perencanaan (planning)

d. Analisis kebutuhan (requirements analysis)

e. Desain (design)

f. Pengembangan (development)

g. Integrasi dan pengujian (integration and test) 
h. Implementasi (implementation)

i. Operasi dan pemeliharaan (operations and maintenance)

j. Disposisi (disposition)

(A.S, Rosa dan Shalahuddin, M., 2014)

\section{Model Waterfall}

Model SDLC air terjun (waterfall) sering juga disebut model sekuensial linier (sequential linear) atau alur hidup klasik (classic life cycle). Model air terjun menyediakan pendekatan alur hidup perangkat lunak secara sekuensial atau terurut dimulai dari analisis, desain, pengodean, pengujian, dan tahap pendukung (support).

Kenyataannya sangat jarang model air terjun dapat dilakukan sesuai alurnya karena sebab sebagai berikut

a. Perubahan spesifikasi perangkat lunak terjadi di tengah alur pengembangan.

b. Sangat sulit bagi pelanggan untuk mendefinisikan semua spesifikasi di awal alur pengembangan. Pelanggan sering kali butuh contoh (prototype) untuk menjabarkan spesifikasi kebutuhan sistem lebih lanjut.

c. Pelanggan tidak mungkin bersabar mengakomodasi perubahan yang diperlukan di akhir alur pengembangan.

Model ini sangat cocok digunakan kebutuhan pelanggan sudah sangat dipahami dan kemungkinan terjadinya perubahan kebutuhan selama pengembangan perangkat lunak kecil. Hal positif dari model air terjun adalah struktur tahap pengembangan sistem jelas, dokumentasi dihasilkan di setiap tahap pengembangan, dan sebuah tahap dijalankan setelah tahap sebelumnya selesai dijalankan (tidak ada tumpang tindih pelaksanaan tahap). (A.S, Rosa dan Shalahuddin, M., 2014)

\section{ERD}

Pemodelan awal basis data yang paling banyak digunakan adalah menggunakan Entity Relationship Diagram (ERD). ERD dikembangkan berdasarkan teori himpunan dalam bidang matematika. ERD digunakan untuk pemodelan basis data relasional. Sehingga jika penyimpanan basis data menggunakan OODBMS maka perancangan basis data tidak perlu menggunakan ERD. (A.S, Rosa dan Shalahuddin, M., 2014)

\section{E. $U M L$}

UML adalah bahasa spesifikasi standar yang dipergunakan untuk mendokumentasikan, menspesifikasikan dan membangun perangkat lunak. UML merupakan metodologi dalam mengembangkan sistem berorientasi objek dan juga merupakan alat untuk mendukung pengembangan sistem. UML saat ini sangat banyak dipergunakan dalam dunia industri yang merupakan standar bahasa pemodelan umum dalam industri perangkat lunak dan pengembangan sistem. (Gata, Windu dan Gata, Grace, 2013)

\section{F. Use Case}

Use Case Diagram merupakan pemodelan untuk kelakuan (behavior) sistem informasi yang akan dibuat. Use Case mendeskripsikan sebuah interaksi antara satu atau lebih aktor dengan sistem informasi yang akan dibuat. Dapat dikatakan Use Case digunakan untuk mengetahui fungsi apa saja yang ada di dalam sistem informasi dan siapa saja yang berhak menggunakan fungsi-fungsi tersebut. (Gata, Windu dan Gata, Grace, 2013)

\section{G. Sequence diagram}

Sequence diagram menggambarkan kelakuan objek pada Use Case dengan mendeskripsikan waktu hidup objek dan pesan yang dikirimkan dan diterima antar objek.(Gata, Windu dan Gata, Grace, 2013)

\section{H. Class diagram}

Class diagram merupakan hubungan antar kelas dan penjelasan detail tiap-tiap kelas di dalam model desain dari suatu sistem, juga memperlihatkan aturan-aturan dan tanggung jawab entitas yang menentukan perilaku sistem. Class diagram juga menunjukkan atribut-atribut dan operasi-operasi dari sebuah kelas dan constraint yang berhubungan dengan objek yang dikoneksikan. (Gata, Windu dan Gata, Grace, 2013)

\section{I. $P H P$}

PHP merupakan singkatan dari Hypertext Preprocessor yang merupakan bahasa berbentuk skrip yang ditempatkan pada server dan diproses di server. Hasilnya kemudian dikirimkan ke browser klien. (Hirin A.M dan Virgi, 2011)

\section{J. Javasript}

Javascript adalah bahasa yang berbentuk kumpulan skrip yang pada fungsinya berjalan pada suatu dokumen HTML. Sepanjang sejarah internet bahasa ini adalah bahasa skrip pertama untuk web. Bahasa ini adalah bahasa pemrograman untuk memberikan kemampuan tambahan terhadap HTML dengan mengijinkan pengeksekusian perintah-perintah di sisi klien, yang artinya di sisi browser bukan di sisi server. (Adi, A.P dan Sanjay, R., 2012)

\section{K. Code Igniter}

Code Igniter adalah aplikasi open source yang berupa framework dengan model MVC (model view controller) untuk membangun website dinamis. Dengan menggunakan PHP Code Igniter akan memudahkan developer untuk membuat aplikasi web dengan cepat dan mudah dibandingkan dengan membuatnya dari awal. (Wiswakrma, Komang, 2010)

\section{L. $M y S Q L$}

$M y S Q L$ adalah sebuah perangkat lunak sistem manajemen basis data SQL atau DBMS yang multithread, multi-user dengan sekitar 6 juta instalasi di seluruh dunia. MySQL AB membuat $M y S Q L$ tersedia sebagai perangkat lunak gratis di bawah lisensi $G N U$ General Public Licence (GPL). Tetapi mereka juga 
menjual di bawah lisensi komersial untuk kasus-kasus di mana penggunaannya tida cocok dengan pengunaan GPL. (Wahyono, Teguh, 2009)

\section{PERANCANGAN Sistem}

\section{A. Tahapan Perancangan Sistem}

Tahapan perancangan sistem memiliki tujuan untuk men-desain sistem baru yang dapat menyelsaikan masalah-masalah yang dihadapi organisasi atau perusahaan. Software Development Live Cycle adalah proses mengembangkan atau mengubah suatu sistem perangkat lunak dengan menggunakan model-model yang digunakan orang untuk mengembangkan sistemsistem perangkat lunak sebelumnya. Model yang digunakan dalam penelitian tugas akhir ini adalah model waterfall. Model waterfall terdiri dari 5 tahap yaitu Analisis Kebutuhan, Desain, Pengodean, Pengujian dan Pemeliharaan.

\section{B. Analisis Kebutuhan}

Tahapan analisis kebutuhan dilakukan untuk menspesifikasikan kebutuhan perangkat lunak agar dapat dipahami perangkat seperti apa yang diinginkan user dan kemudian mentransformasikan ke dalam sebuah deskripsi yang jelas dan lengkap.

1. Kebutuhan Pengguna

Setelah mendeskripsikan tahapan kerja dan disertai informasi serta kendala yang ada, didapatkan kebutuhan untuk kemudahan memanajemen data pada UNDIP distro. Kebutuhan tersebut adalah :

1. Mengelola data pemesanan

2. Mengelola data produk

3. Mengelola data member

4. Mengelola laporan penjualan

2. Aktor yang Terlibat

Terdapat beberapa aktor yang terlibat dalam pembuatan aplikasi manajemen ini, yaitu :

1. Superadmin

Super admin Memiliki wewenang untuk mengelola data akun, teridiri dari:

a. Mencari data akun

b. Menambah data akun

c. Menghapus data akun

d. Mengubah data akun

2. Admin

Admin yang memiliki wewenang untuk:

a. Mengelola data kategori.

b. Mengelola data data produk.

c. Mengelola data pesanan

d. Mengelola data slide

e. Mengelola laporan penjualan

3. Member

Member memiliki wewenang untuk:

a. Mendaftar

b. Mengubah profil

c. Memesan produk

d. Mengirim kotak surat

\section{Desain}

Tahap perancangan / desain perangkat lunak merupakan proses multi langkah dan berfokus pada beberapa atribut perangkat lunak. Proses ini berdasarkan dari analisa sebelumnya sehingga menciptakan sebuah rancangan yang sesuai dengan kebutuhan dari pihak terkait. Dalam perancangan perangkat lunak ini, digunakan Entity Relationship Diagram (ERD) untuk pemodelan basis data dan UML untuk pemodelan perangkat lunak.

\section{ERD}

Entity Relationship Diagram (ERD) adalah salah satu metode pemodelan data yang digunakan untuk menggambarkan suatu basis data.

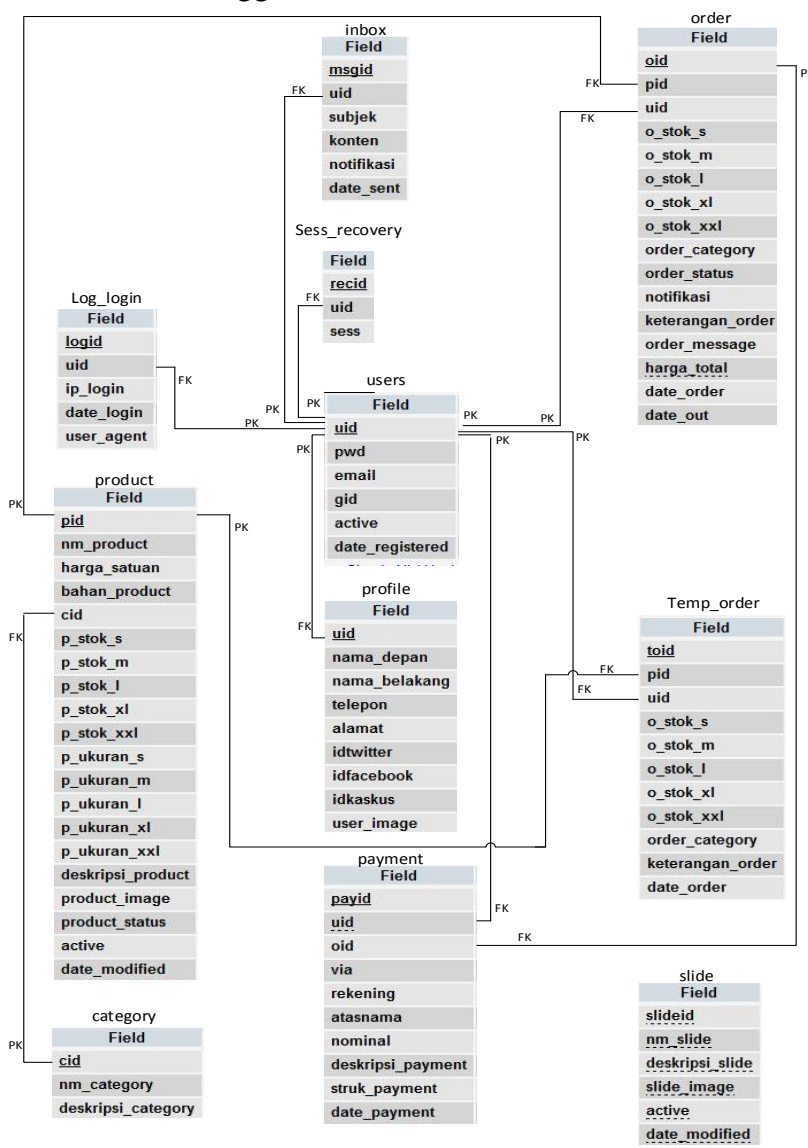

Gambar 1 Skema Basis Data UNDIP distro 
2. UML

a. Usecase Diagram

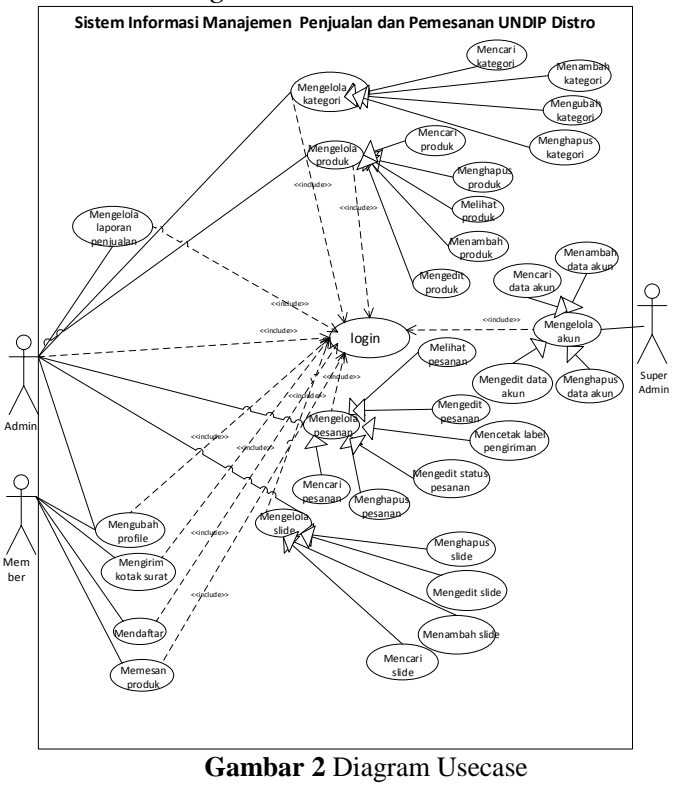

b. Struktur Model, View dan Controller (MVC) Berikut ini merupakan struktur MVC aplikasi manajemen UNDIP distro

Table 1 Struktur MVC aplikasi Manajemen UNDIP distro

\begin{tabular}{|l|l|l|l|}
\hline Fungsi & $\begin{array}{l}\text { Model } \\
\text { (fungsi) }\end{array}$ & $\begin{array}{l}\text { Controller } \\
\text { (fungsi) }\end{array}$ & View \\
\hline 1. Logout & - & Home (logout) & - \\
\hline 2. Login & $\begin{array}{l}\text { Akun } \\
\text { (getPersona } \\
\text { 1Akun) }\end{array}$ & Home (login) & Login \\
\hline $\begin{array}{l}\text { 3. Hapus } \\
\text { akun }\end{array}$ & $\begin{array}{l}\text { Akun } \\
\text { (getAllAcc } \\
\text { ount, } \\
\text { deleteAkun, } \\
\text { delete } \\
\text { profile) }\end{array}$ & Super (account) & - \\
& $\begin{array}{l}\text { Akun } \\
\text { (getAllAcc } \\
\text { ount, } \\
\text { insertNew } \\
\text { akun }\end{array}$ & Super (account) & account_ \\
& $\begin{array}{l}\text { Member, } \\
\text { getPersonal } \\
\text { Data, } \\
\text { insertNewP } \\
\text { rofile) }\end{array}$ & & \\
& & \\
& & \\
& & \\
& & \\
& & \\
\end{tabular}

c. Sequence Diagram

Berkut ini adalah gambar-gambar Diagram Sequence dari Aplikasi Manajemen UNDIP Distro

Gambar 3 merupakan digram sekuensial untuk keluar dari sistem (logout)

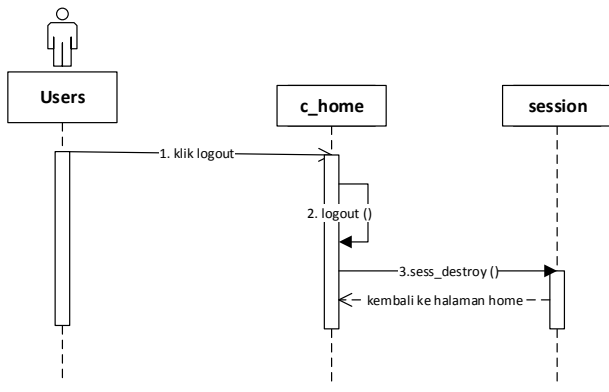

Gambar 3 Diagram sekuensial keluar dari sistem (logout)

Gambar 4 merupakan digram sekuensial login

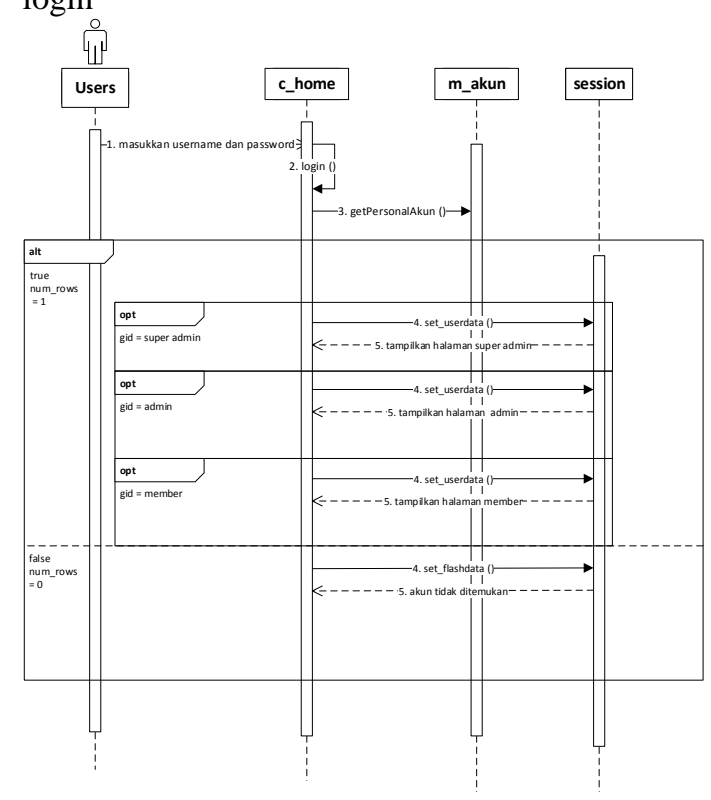

. Gambar 4 Diagram sekuensial dari login

Gambar 5 merupakan digram sekuensial dari menghapus akun

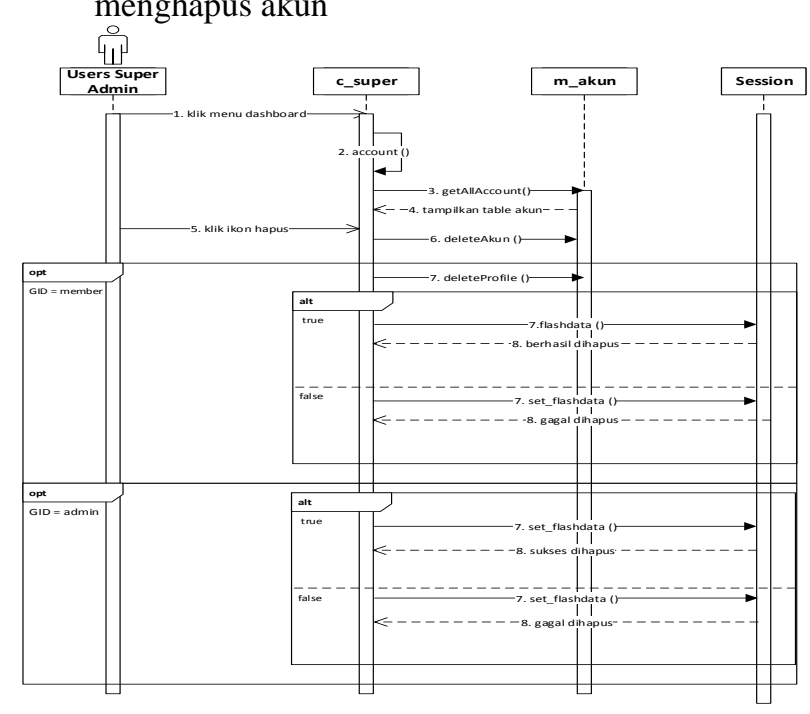

Gambar 6 Diagram sekuensial dari menghapus akun 


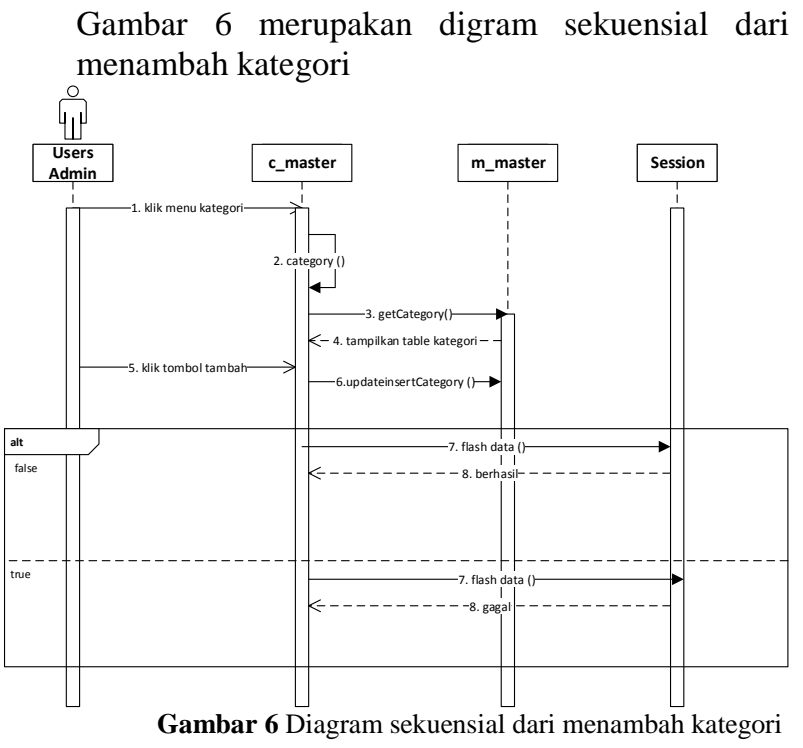

Gambar 7 merupakan digram sekuensial dari menghapus kategori.

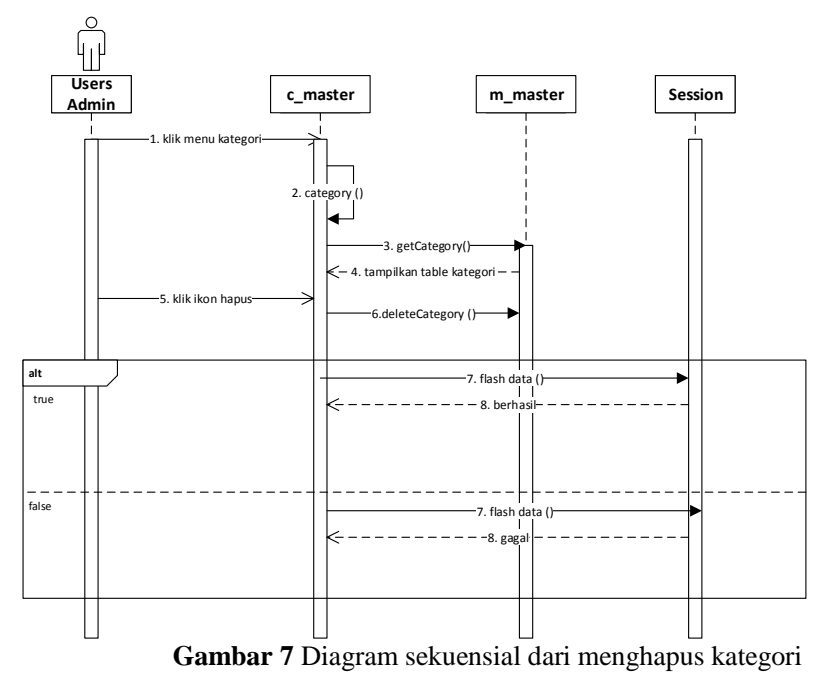

IV. IMPLEMENTASI DAN PENGUJIAN

\section{A. Implementasi Basis Data}

Tahapan ini mengimplementasikan hasil perancangan basis pada sistem yang telah dibuat sebelumnya.

Gambar 8 merupakan contoh implementasi pada tabel kategori

\begin{tabular}{|l|l|l|}
\hline \multicolumn{1}{|c|}{ Field } & \multicolumn{1}{|c|}{ Type } \\
\hline$\square$ & $\underline{\text { cid }}$ & int(3) \\
\hline$\square$ & nm_category & $\operatorname{varchar(25)}$ \\
\hline$\square$ & deskripsi_category & text \\
\hline
\end{tabular}

Gambar 8 Implementasi tabel kategori

Implementasi tabel yang lain ditunjukkan oleh gambar 9 sampai dengan gambar 20 .

\begin{tabular}{|l|l|l|}
\hline & \multicolumn{1}{|c|}{ Field } & \multicolumn{1}{|c|}{ Type } \\
\hline$\square$ & msgid & int(11) \\
\hline$\square$ & uid & $\operatorname{varchar}(25)$ \\
\hline$\square$ & subjek & varchar(30) \\
\hline$\square$ & konten & mediumtext \\
\hline$\square$ & notifikasi & enum(1',"0') \\
\hline$\square$ & date_sent & date \\
\hline
\end{tabular}

Gambar 9 Implementasi tabel inboxe

\begin{tabular}{|l|l|l|}
\hline & \multicolumn{1}{|c|}{ Field } & \multicolumn{1}{c|}{ Type } \\
\hline$\square$ & logid & int(4) \\
\hline$\square$ & uid & varchar(25) \\
\hline$\square$ & ip_login & varchar(15) \\
\hline$\square$ & date_login & date \\
\hline$\square$ & user_agent & varchar(10) \\
\hline
\end{tabular}

Gambar 10 Implementasi tabel log_login

\begin{tabular}{|l|l|l|}
\hline \multicolumn{2}{|c|}{ Field } & \multicolumn{2}{|c|}{ Type } \\
\hline$\square$ & oid & int(11) \\
\hline$\square$ & pid & varchar(15) \\
\hline$\square$ & uid & varchar(4) \\
\hline$\square$ & o_stok_s & int(4) \\
\hline$\square$ & o_stok_m & int(4) \\
\hline$\square$ & o_stok_I & int(4) \\
\hline$\square$ & o_stok_xl & int(4) \\
\hline$\square$ & o_stok_xxl & int(4) \\
\hline$\square$ & order_category & enum('ready','preorder') \\
\hline$\square$ & order_status & enum('pesan','tunggu','setuju','tolak') \\
\hline$\square$ & notifikasi & enum(1','0') \\
\hline$\square$ & keterangan_order & text \\
\hline$\square$ & order_message & text \\
\hline$\square$ & harga_total & int(10) \\
\hline$\square$ & date_order & date \\
\hline$\square$ & date_out & date \\
\hline
\end{tabular}

Gambar 11 Implementasi tabel order

\begin{tabular}{|l|l|l|}
\hline \multicolumn{1}{|c|}{ Field } & \multicolumn{1}{|c|}{ Type } \\
\hline$\square$ & payid & int(4) \\
\hline$\square$ & uidd & varchar(25) \\
\hline$\square$ & oid & int(4) \\
\hline$\square$ & via & varchar(25) \\
\hline$\square$ & rekening & varchar(25) \\
\hline$\square$ & atasnama & varchar(25) \\
\hline$\square$ & nominal & int(4) \\
\hline$\square$ & deskripsi_payment & text \\
\hline$\square$ & struk_payment & varchar(25) \\
\hline$\square$ & date_payment & date \\
\hline
\end{tabular}

Gambar 12 Implementasi tabel order

\begin{tabular}{|l|l|l|}
\hline \multicolumn{1}{|c|}{ Field } & \multicolumn{1}{|c|}{ Type } \\
\hline$\square$ & pid & varchar(15) \\
\hline$\square$ & nm_product & varchar(15) \\
\hline$\square$ & harga_satuan & int(4) \\
\hline$\square$ & bahan_product & text \\
\hline$\square$ & cid & int(2) \\
\hline$\square$ & P_stok_s & int(4) \\
\hline$\square$ & P_stok_m & int(4) \\
\hline$\square$ & P_stok_I & int(4) \\
\hline$\square$ & P_stok_xl & int(4) \\
\hline$\square$ & P_stok_xxl & int(4) \\
\hline$\square$ & P_ukuran_s & varchar(25) \\
\hline$\square$ & P_ukuran_m & varchar(25) \\
\hline$\square$ & P_ukuran_I & varchar(25) \\
\hline$\square$ & P_ukuran_xl & varchar(25) \\
\hline$\square$ & P_ukuran_xxl & varchar(25) \\
\hline$\square$ & deskripsi_product & mediumtext \\
\hline$\square$ & product_image & varchar(50) \\
\hline$\square$ & product_status & enum('ready','preorder') \\
\hline$\square$ & active & enum(1','0') \\
\hline$\square$ & date_modified & date \\
\hline Gambar 13 Implementasi tabel product \\
\hline
\end{tabular}




\begin{tabular}{|l|l|l|}
\hline \multicolumn{1}{|c|}{ Field } & \multicolumn{1}{|c|}{ Type } \\
\hline$\square$ & uid & $\operatorname{varchar(25)}$ \\
\hline$\square$ & nama_depan & $\operatorname{varchar(30)}$ \\
\hline$\square$ & nama_belakang & $\operatorname{varchar(15)}$ \\
\hline$\square$ & telepon & varchar(25) \\
\hline$\square$ & alamat & text \\
\hline$\square$ & idtwitter & varchar(35) \\
\hline$\square$ & idfacebook & $\operatorname{varchar}(35)$ \\
\hline$\square$ & idkaskus & $\operatorname{varchar}(35)$ \\
\hline$\square$ & user_image & $\operatorname{varchar}(50)$ \\
\hline
\end{tabular}

Gambar 14 Implementasi tabel profile

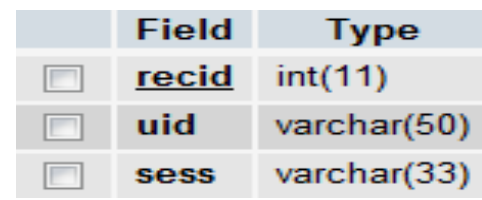

Gambar 15 Implementasi tabel sess_recovery

\begin{tabular}{|l|l|l|}
\hline \multicolumn{1}{|c|}{ Field } & \multicolumn{1}{c|}{ Type } \\
\hline$\square$ & slideid & int(4) \\
\hline$\square$ & nm_slide & $\operatorname{varchar}(100)$ \\
\hline$\square$ & deskripsi_slide & text \\
\hline$\square$ & slide_image & varchar(100) \\
\hline$\square$ & active & enum('1,'0') \\
\hline$\square$ & date_modified & date \\
\hline
\end{tabular}

Gambar 16 Implementasi tabel slide

\begin{tabular}{|c|c|c|}
\hline & Field & Type \\
\hline$\square$ & toid & $\operatorname{int}(11)$ \\
\hline$\square$ & pid & varchar(15) \\
\hline$\square$ & uid & varchar(50) \\
\hline$\square$ & o_stok_s & $\operatorname{int}(11)$ \\
\hline$\square$ & o_stok_m & $\operatorname{int}(11)$ \\
\hline$\square$ & o_stok_I & $\operatorname{int}(11)$ \\
\hline 回 & o_stok_xl & $\operatorname{int}(11)$ \\
\hline$\square$ & o_stok_xxl & $\operatorname{int}(11)$ \\
\hline$\square$ & order_category & enum('ready','preorder') \\
\hline$\square$ & keterangan_orde & er text \\
\hline$\square$ & date_order & date \\
\hline \multicolumn{3}{|c|}{ Gambar 17 Implementasi tabel temp_order } \\
\hline & Field & Type \\
\hline$\square$ & $\underline{\text { uid }}$ & $\operatorname{varchar}(35)$ \\
\hline$\square$ & pwd & $\operatorname{varchar}(33)$ \\
\hline$\square$ & email & $\operatorname{varchar}(35)$ \\
\hline$\square$ & gid & enum('member','admin','su') \\
\hline$\square$ & active & enum( $\left(1,{ }^{\prime}, 0^{\prime}\right)$ \\
\hline$\square$ & date_registered & date \\
\hline
\end{tabular}

\section{B. Implementasi Antarmuka}

Berikut ini merupakan antarmuka yang dimiliki Aplikasi Manajemen UNDIP Distro

\section{Halaman Login}

Berisi form untuk melakukan login ke aplikasi dengan memasukkan username dan password, tampilan seperti pada gambar 19 .

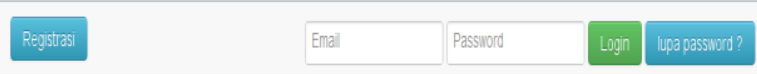

Gambar 19 Halaman Login
2. Halaman Super Admin

Berisi halaman dari super admin, tampilan seperti pada Gambar 20.

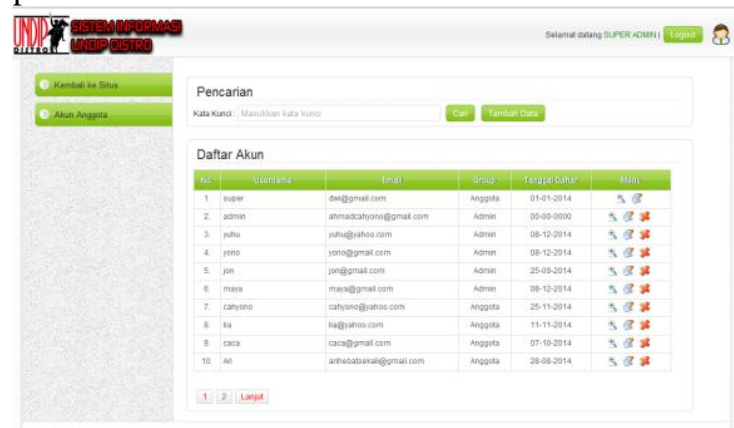

Gambar 20 Halaman Super Admin

\section{Halaman Admin}

Berisi halaman dari admin, tampilan seperti pada Gambar 21.

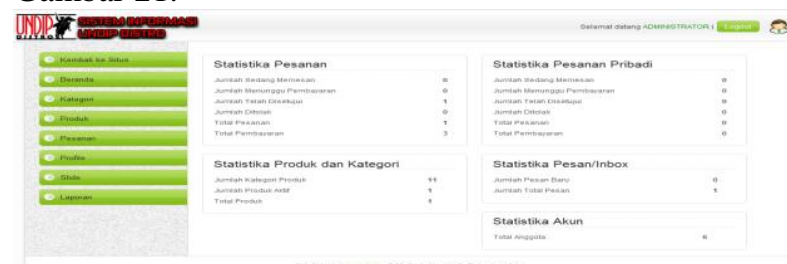

Gambar 21 Halaman Master DPL

4. Halaman Member

Berisi fitur untuk mengelola data kabupaten, tampilan seperti pada Gambar 22.

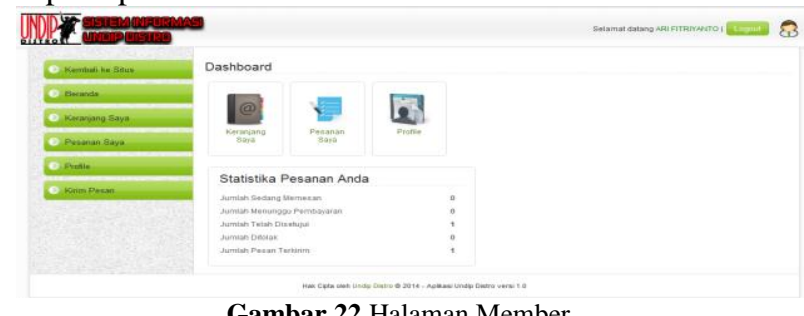

Gambar 22 Halaman Member

\section{Pengujian}

Proses pengujian dilakukan menggunakan metode black-box berdasarkan fungsi dari aplikasi yang tertera pada diagram use case.

Tabel-tabel di bawah ini merupakan ringkasan dari pengujian yang telah dilakukan.

Tabel 2 Pengujian users super admin

\begin{tabular}{|c|c|c|c|}
\hline $\begin{array}{l}\text { Nama } \\
\text { Pengujia } \\
\text { n } \\
\end{array}$ & $\begin{array}{l}\text { Bentuk } \\
\text { Pengujian }\end{array}$ & $\begin{array}{l}\text { Hasil yang } \\
\text { diharapkan }\end{array}$ & $\begin{array}{l}\text { Hasil } \\
\text { Pengujian }\end{array}$ \\
\hline $\begin{array}{l}\text { Pengujian } \\
\text { login }\end{array}$ & $\begin{array}{l}\text { Memasukkan } \\
\text { username } \\
\text { dan password } \\
\text { yang } \\
\text { digunakan } \\
\text { untuk login }\end{array}$ & $\begin{array}{l}\text { Muncul ke } \\
\text { halaman }\end{array}$ & Berhasil \\
\hline $\begin{array}{l}\text { Pengujian } \\
\text { mencari } \\
\text { data akun }\end{array}$ & $\begin{array}{l}\text { Memasukkan } \\
\text { kata kunci ke } \\
\text { kolom } \\
\text { pencarian }\end{array}$ & $\begin{array}{l}\text { Muncul akun } \\
\text { yang dicari }\end{array}$ & Berhasil \\
\hline $\begin{array}{l}\text { Pengujian } \\
\text { menamba } \\
\text { h data }\end{array}$ & $\begin{array}{l}\text { Memasukkan } \\
\text { data akun } \\
\text { baru dan }\end{array}$ & $\begin{array}{l}\text { Muncul data } \\
\text { akun baru } \\
\text { berhasil }\end{array}$ & Berhasil \\
\hline
\end{tabular}




\begin{tabular}{|l|l|l|l|}
\hline akun & $\begin{array}{l}\text { menyimpann } \\
\text { ya }\end{array}$ & $\begin{array}{l}\text { ditambahkan dan } \\
\text { data ditampilkan } \\
\text { pada daftar }\end{array}$ & \\
\hline $\begin{array}{l}\text { Pengujian } \\
\text { menghapu } \\
\text { s data } \\
\text { akun }\end{array}$ & $\begin{array}{l}\text { Memilih data } \\
\text { akun tertentu } \\
\text { dan } \\
\text { menghapus } \\
\text { data akun } \\
\text { tersebut }\end{array}$ & $\begin{array}{l}\text { Muncul pesan } \\
\text { data akun berhasi } \\
\text { dihapus dan } \\
\text { menghilang dari } \\
\text { daftar }\end{array}$ & Berhasil \\
\hline $\begin{array}{l}\text { Pengujian } \\
\text { mengedit } \\
\text { data akun }\end{array}$ & $\begin{array}{l}\text { Memilih data } \\
\text { akun yang } \\
\text { tersedia, } \\
\text { mngklik icon } \\
\text { edit dan } \\
\text { mengubah } \\
\text { informasinya }\end{array}$ & $\begin{array}{l}\text { Muncul pesan } \\
\text { data akun }\end{array}$ & $\begin{array}{l}\text { Berhasil } \\
\text { diperbaharui } \\
\text { informasinya }\end{array}$ \\
\\
\hline
\end{tabular}

Tabel 5 Pengujian users admin mengelola data produk

\begin{tabular}{|c|c|c|c|}
\hline $\begin{array}{l}\text { Nama } \\
\text { Pengujian }\end{array}$ & $\begin{array}{l}\text { Bentuk } \\
\text { Pengujian }\end{array}$ & $\begin{array}{l}\text { Hasil yang } \\
\text { diharapkan }\end{array}$ & $\begin{array}{l}\text { Hasil } \\
\text { Pengujian }\end{array}$ \\
\hline $\begin{array}{l}\text { Pengujian } \\
\text { mencari } \\
\text { produk }\end{array}$ & $\begin{array}{l}\text { Memasukkan } \\
\text { kata kunci } \\
\text { pencarian } \\
\text { dalam form } \\
\text { pencaria }\end{array}$ & $\begin{array}{l}\text { Muncul kata } \\
\text { yang diketikkan } \\
\text { di form } \\
\text { pencarian dan } \\
\text { menampilkan } \\
\text { dalam daftar }\end{array}$ & Berhasil \\
\hline $\begin{array}{l}\text { Pengujian } \\
\text { melihat } \\
\text { produk }\end{array}$ & $\begin{array}{l}\text { Mengklik } \\
\text { menu produk }\end{array}$ & $\begin{array}{l}\text { Muncul daftar } \\
\text { produk yang ada } \\
\text { dalam daftar }\end{array}$ & Berhasil \\
\hline $\begin{array}{l}\text { Pengujian } \\
\text { menambah } \\
\text { produk }\end{array}$ & $\begin{array}{l}\text { Memasukkan } \\
\text { produk ke } \\
\text { dalam daftar } \\
\text { produk }\end{array}$ & $\begin{array}{l}\text { Muncul pesan } \\
\text { produk berhasil } \\
\text { ditambahkan dan } \\
\text { ditampilkan } \\
\text { dalam daftar }\end{array}$ & Berhasil \\
\hline $\begin{array}{l}\text { Pengujian } \\
\text { mengedit } \\
\text { produk }\end{array}$ & $\begin{array}{l}\text { Memilih } \\
\text { produk yang } \\
\text { akan } \\
\text { diperbaharui } \\
\text { dan } \\
\text { mengklik } \\
\text { icon edit } \\
\end{array}$ & $\begin{array}{l}\text { Muncul pesan } \\
\text { berhasil } \\
\text { memperbaharui } \\
\text { produk dan } \\
\text { menampilkannya } \\
\text { dalam daftar }\end{array}$ & Berhasil \\
\hline $\begin{array}{l}\text { Pengujian } \\
\text { menghapus } \\
\text { produk }\end{array}$ & $\begin{array}{l}\text { Memilih } \\
\text { produk dan } \\
\text { mengklik } \\
\text { icon hapus }\end{array}$ & $\begin{array}{l}\text { Muncul pesan } \\
\text { memperbaharui } \\
\text { berhasil dan } \\
\text { menampilkannya } \\
\text { dalam daftar } \\
\text { produk }\end{array}$ & Berhasil \\
\hline
\end{tabular}

Tabel 3 Pengujian users member

\begin{tabular}{|l|l|l|l|}
\hline $\begin{array}{l}\text { Nama } \\
\text { Pengujia }\end{array}$ & $\begin{array}{l}\text { Bentuk } \\
\text { Pengujian }\end{array}$ & $\begin{array}{l}\text { Hasil yang } \\
\text { diharapkan }\end{array}$ & $\begin{array}{l}\text { Hasil } \\
\text { Pengujian }\end{array}$ \\
\hline $\begin{array}{l}\text { Pengujian } \\
\text { mendaftar }\end{array}$ & $\begin{array}{l}\text { Mengisi } \\
\text { form } \\
\text { registrasi }\end{array}$ & $\begin{array}{l}\text { Muncul pesan } \\
\text { pendaftaran akun } \\
\text { baru berhasil }\end{array}$ & Berhasil \\
\hline $\begin{array}{l}\text { Pengujian } \\
\text { memesan } \\
\text { produk }\end{array}$ & $\begin{array}{l}\text { Mengisi } \\
\text { form } \\
\text { pemesanan } \\
\text { produk }\end{array}$ & $\begin{array}{l}\text { Muncul pesan } \\
\text { pemesanan } \\
\text { produk berhasil } \\
\text { dilakukan }\end{array}$ & Berhasil \\
\hline $\begin{array}{l}\text { Pengujian } \\
\text { mengubah } \\
\text { profil }\end{array}$ & $\begin{array}{l}\text { Memilih } \\
\text { form untuk } \\
\text { diperbaharui } \\
\text { informasi }\end{array}$ & $\begin{array}{l}\text { Muncul pesan } \\
\text { berhasil } \\
\text { memperbaharui } \\
\text { profil }\end{array}$ & Berhasil \\
\hline $\begin{array}{l}\text { Pengujian } \\
\text { mengirim } \\
\text { kotak } \\
\text { surat }\end{array}$ & $\begin{array}{l}\text { Mengirim } \\
\text { pesan di } \\
\text { form yang } \\
\text { tersedia }\end{array}$ & $\begin{array}{l}\text { Muncul pesan } \\
\text { bahwa pesan } \\
\text { berhasil dikirim }\end{array}$ & Berhasil \\
\hline
\end{tabular}

Tabel 4 Pengujian users admin mengelola data kategori

\begin{tabular}{|c|c|c|c|}
\hline $\begin{array}{l}\text { Nama } \\
\text { Pengujia } \\
\text { n }\end{array}$ & $\begin{array}{l}\text { Bentuk } \\
\text { Pengujian }\end{array}$ & $\begin{array}{l}\text { Hasil yang } \\
\text { diharapkan }\end{array}$ & $\begin{array}{l}\text { Hasil } \\
\text { Pengujian }\end{array}$ \\
\hline $\begin{array}{l}\text { Pengujian } \\
\text { mencari } \\
\text { kategori }\end{array}$ & $\begin{array}{l}\text { Memasukkan } \\
\text { kata kunci } \\
\text { pencarian ke } \\
\text { form } \\
\text { pencarian }\end{array}$ & $\begin{array}{l}\text { Muncul pesan } \\
\text { pencarian ada } \\
\text { dalam daftar }\end{array}$ & Berhasil \\
\hline $\begin{array}{l}\text { Pengujian } \\
\text { menamba } \\
\text { h kategori }\end{array}$ & $\begin{array}{l}\text { Memasukkan } \\
\text { kategori ke } \\
\text { dalam daftar }\end{array}$ & $\begin{array}{l}\text { Muncul pesan } \\
\text { kategori berhasil } \\
\text { dan tampil pada } \\
\text { daftar }\end{array}$ & Berhasil \\
\hline $\begin{array}{l}\text { Pengujian } \\
\text { mengubah } \\
\text { kategori }\end{array}$ & $\begin{array}{l}\text { Memilih } \\
\text { kategori } \\
\text { yang akan } \\
\text { diperbaharui } \\
\text { dan } \\
\text { mengklik } \\
\text { icon edit }\end{array}$ & $\begin{array}{l}\text { Muncul pesan } \\
\text { bahwa } \\
\text { memperbaharui } \\
\text { kategori berhasil } \\
\text { dan ditampilkan } \\
\text { dalam daftar }\end{array}$ & Berhasil \\
\hline $\begin{array}{l}\text { Pengujian } \\
\text { menghapu } \\
\text { s kategori }\end{array}$ & $\begin{array}{l}\text { Memilih } \\
\text { kategori } \\
\text { yang akan di } \\
\text { hapus } \\
\text { dengan } \\
\text { mengklik } \\
\text { tombol } \\
\text { hapus }\end{array}$ & $\begin{array}{l}\text { Muncul pesan } \\
\text { kategori berhasil } \\
\text { dihapus dan } \\
\text { menghilang dari } \\
\text { daftar }\end{array}$ & Berhasil \\
\hline
\end{tabular}

Tabel 6. Pengujian Users Admin mengelola data slide

\begin{tabular}{|l|l|l|l|}
\hline $\begin{array}{l}\text { Nama } \\
\text { Pengujian }\end{array}$ & $\begin{array}{l}\text { Bentuk } \\
\text { Pengujian }\end{array}$ & $\begin{array}{l}\text { Hasil yang } \\
\text { diharapkan }\end{array}$ & $\begin{array}{l}\text { Hasil } \\
\text { Pengujian }\end{array}$ \\
\hline $\begin{array}{l}\text { Pengujian } \\
\text { slide }\end{array}$ & $\begin{array}{l}\text { Memasukkan } \\
\text { kata kunci } \\
\text { pencarian di } \\
\text { form } \\
\text { pencarian }\end{array}$ & $\begin{array}{l}\text { Muncul kata } \\
\text { kunci sesuai } \\
\text { yang } \\
\text { dimasukkan ke } \\
\text { dalam form } \\
\text { pencarian }\end{array}$ & Berhasil \\
\hline $\begin{array}{l}\text { Pengujian } \\
\text { mengedit } \\
\text { slide }\end{array}$ & $\begin{array}{l}\text { Memilih } \\
\text { slide yang } \\
\text { akan } \\
\text { diperbaharui } \\
\text { dan } \\
\text { mengklik } \\
\text { icon edit }\end{array}$ & $\begin{array}{l}\text { Muncul pesan } \\
\text { baerhasil } \\
\text { memperbaharui } \\
\text { slide dan } \\
\text { menampilkan } \\
\text { ke daftar }\end{array}$ & Berhasil \\
\hline $\begin{array}{l}\text { Pengujian } \\
\text { menghapus } \\
\text { slide }\end{array}$ & $\begin{array}{l}\text { Memilih } \\
\text { slide yang } \\
\text { akan dihapus } \\
\text { dan } \\
\text { mengklik } \\
\text { icon hapus }\end{array}$ & $\begin{array}{l}\text { Muncul pesan } \\
\text { berhasil } \\
\text { menghapus } \\
\text { slide dan } \\
\text { menghilangkan } \\
\text { dari daftar slide }\end{array}$ & Berhasil \\
\hline $\begin{array}{l}\text { Pengujian } \\
\text { menambah } \\
\text { slide }\end{array}$ & $\begin{array}{l}\text { Memasukkan } \\
\text { slide baru ke } \\
\text { dalam daftar }\end{array}$ & & Berhasil \\
\hline
\end{tabular}


Tabel 7. Pengujian users admin mengelola order

\begin{tabular}{|c|c|c|c|}
\hline $\begin{array}{l}\text { Nama } \\
\text { Pengujian }\end{array}$ & $\begin{array}{l}\text { Bentuk } \\
\text { Pengujian }\end{array}$ & $\begin{array}{l}\text { Hasil yang } \\
\text { diharapkan }\end{array}$ & $\begin{array}{l}\text { Hasil } \\
\text { Pengujian }\end{array}$ \\
\hline $\begin{array}{l}\text { Pengujian } \\
\text { melihat } \\
\text { pesanan }\end{array}$ & $\begin{array}{l}\text { Menekan } \\
\text { menu } \\
\text { pesanan }\end{array}$ & $\begin{array}{l}\text { Muncul menu } \\
\text { pesanan dan } \\
\text { menampilkan ke } \\
\text { daftar }\end{array}$ & Berhasil \\
\hline $\begin{array}{l}\text { Pengujian } \\
\text { mengedit } \\
\text { pesanan }\end{array}$ & $\begin{array}{l}\text { Memilih } \\
\text { daftar } \\
\text { pesanan } \\
\text { yang akan } \\
\text { diperbaharui } \\
\text { dan } \\
\text { mengklik } \\
\text { icon edit }\end{array}$ & $\begin{array}{l}\text { Muncul form } \\
\text { edit pesanan dan } \\
\text { berhasil } \\
\text { mengedit } \\
\text { pesanan } \\
\text { menampilkan ke } \\
\text { dalam daftar }\end{array}$ & Berhasil \\
\hline $\begin{array}{l}\text { Pengujian } \\
\text { mengedit } \\
\text { status } \\
\text { pesanan }\end{array}$ & $\begin{array}{l}\text { Memilih } \\
\text { menu } \\
\text { pesanan }\end{array}$ & $\begin{array}{l}\text { Muncul form } \\
\text { edit status } \\
\text { pesanan dan } \\
\text { menampilkan ke } \\
\text { dalam daftar }\end{array}$ & Berhasil \\
\hline $\begin{array}{l}\text { Pengujian } \\
\text { mencari } \\
\text { pesanan }\end{array}$ & $\begin{array}{l}\text { Memasukkan } \\
\text { kata kunci } \\
\text { kata } \\
\text { pencarian di } \\
\text { form } \\
\text { pencarian }\end{array}$ & $\begin{array}{l}\text { Muncul pesan } \\
\text { data pesanan } \\
\text { sesuai dengan } \\
\text { kata kunci yang } \\
\text { dimasukkan dan } \\
\text { menampilkan ke } \\
\text { dalam daftar }\end{array}$ & Berhasil \\
\hline $\begin{array}{l}\text { Pengujian } \\
\text { menghapus } \\
\text { pesanan }\end{array}$ & $\begin{array}{l}\text { Memilih } \\
\text { daftar } \\
\text { pesanan dan } \\
\text { mengklik } \\
\text { icon hapus }\end{array}$ & $\begin{array}{l}\text { Muncul pesan } \\
\text { data pesanan } \\
\text { berhasil dihapus } \\
\text { dan menghilang } \\
\text { dari daftar }\end{array}$ & Berhasil \\
\hline $\begin{array}{l}\text { Pengujian } \\
\text { mencetak } \\
\text { label } \\
\text { pengiriman }\end{array}$ & $\begin{array}{l}\text { Menekan } \\
\text { menu } \\
\text { pesanan } \\
\text { 'telah } \\
\text { disetujui' } \\
\text { kemudian } \\
\text { mengklik } \\
\text { tombol 'print } \\
\text { label } \\
\text { pengiriman' }\end{array}$ & $\begin{array}{l}\text { Muncul form } \\
\text { label pengiriman } \\
\text { dan } \\
\text { menampilkan } \\
\text { dalam bentuk } \\
\text { pdf }\end{array}$ & Berhasil \\
\hline
\end{tabular}

Tabel 8. Pengujian users admin mengubah profil

\begin{tabular}{|l|l|l|l|}
\hline $\begin{array}{l}\text { Nama } \\
\text { Pengujian }\end{array}$ & $\begin{array}{l}\text { Bentuk } \\
\text { Pengujian }\end{array}$ & $\begin{array}{l}\text { Hasil yang } \\
\text { diharapkan }\end{array}$ & $\begin{array}{l}\text { Hasil } \\
\text { Pengujian }\end{array}$ \\
\hline $\begin{array}{l}\text { Pengujian } \\
\text { mengubah } \\
\text { profil }\end{array}$ & $\begin{array}{l}\text { Memasukkan } \\
\text { password }\end{array}$ & $\begin{array}{l}\text { Muncul pesan } \\
\text { berhasil }\end{array}$ & Berhasil \\
lama dan & memperbaharui & \\
& password & password & \\
& baru ke & & \\
& halaman & & \\
& perbaharui & & \\
\hline
\end{tabular}

Tabel 9. Pengujian users admin mengelola laporan penjualan

\begin{tabular}{|l|l|l|l|}
\hline $\begin{array}{l}\text { Nama } \\
\text { Pengujian }\end{array}$ & $\begin{array}{l}\text { Bentuk } \\
\text { Pengujian }\end{array}$ & $\begin{array}{l}\text { Hasil yang } \\
\text { diharapkan }\end{array}$ & $\begin{array}{l}\text { Hasil } \\
\text { Pengujian }\end{array}$ \\
\hline Pengujian & Memasukkan & Muncul pesan & Berhasil \\
mengelola & tanggal dari & $\begin{array}{l}\text { berhasil } \\
\text { menampilkan }\end{array}$ & \\
laporan & sekian & laporan & \\
penjualan & sampai & penjualan & \\
& sekian ke & & \\
& dalam form & & \\
& laporan & & \\
& penjualan & & \\
\hline
\end{tabular}

\section{PENUTUP}

Kesimpulan dan saran dari hasil penelitian dan pembahasan adalah sebagai berikut.

\section{A. Kesimpulan}

Berdasarkan hasil penelitian dan pembahasan, maka dapat diambil kesimpulan sebagai berikut :

1) Aplikasi ini mempunyai 3 user yaitu, super admin, admin dan member

2) Aplikasi ini memiliki fitur untuk melihat laporan penjualan berdasarkan tanggal, baik itu dalam bentuk tabel dalam sistem maupun ekspor ke dalam bentuk file excel.

3) Super admin berwenang untuk mengelola data akun

4) Admin bertugas untuk mengelola data produk dan data pesanan

5) Aplikasi ini dapat melakukan fungsi pemesanan dan konfirmasi pembayaran secara online

6) Aplikasi ini dapat menampilkan barang dan produk baik itu pre order maupun ready stock

\section{B. Saran}

Terdapat saran dari hasil penelitian yaitu sebagai berikut :

1. Aplikasi Sistem Informasi Manajemen Pemesanan dan Penjualan UNDIP distro dapat dikembangkan ke versi mobile dengan semakin berkembangnya fitufitur smartphone yang ada saat ini.

2. Melakukan backup data secara berkala untuk menanggulangi jika terjadi kehilangan maupun kerusakan data dapat dikembangkan menjadi sebuah fitur baru yang mendukung keterjaminan data pada sistem informasi.

\section{Daftar Pustaka}

[1] A.S, Rosa dan Shalahuddin, M., Modul Pembelajaran Rekayasa Perangkat Lunak (Terstruktur dan Berorientasi Objek), Modula, Bandung, 2011.

[2] Bin Ladjamudin, Al-Bahra, Analisis dan Desain Sistem Informasi, Graha Ilmu, Yogyakarta, 2005.

[3] Pribadi Basuki, Awan, Membangun Web Berbasis PHP dengan Framework CodeIgniter, Lokomedia, Yogyakarta, 2010.

[4] Wiswakarma, Komang., 9 Langkah Menjadi Master Framework CodeIgniter., Loko Media, Yogyakarta, 2010.

[5] Huda, Miftahul., Membuat Aplikasi Database dengan Java, MySQL dan Netbeans, PT. Elex Media Komputindo, Jakarta, 2010. (blm)

[6] Gata, Windu dan Gata, Grace., Sukses Membangung Aplikasi Penjualan dengan Java, PT Elex Media Komputindo, Jakarta, 2013.

[7] A.S, Rosa dan M. Shalahuddin. Modul Pembelajaran Rekayasa Perangkat Lunak, Modula, 2011.

[8] Kadir, Abdul., Dasar Pemrograman Web Dinamis Menggunakan PHP, CV. Andi Offset, Yogyakarta, 2008. 
[9] Riyanto, Slamet, Membangun Web Portal Multibahasa Joomla 1.5X+CD, PT. Elex Media Komputindo, Jakarta, 2009.

[10] Adi, A.P dan Sanjay, R., Web Makin Dahsyat dengan JQuery, Kompas Gramedia. Semarang, 2012.

[11]Septian, Gungun. Trik Pintar Menguasai CodeIgniter, PT. Elex Media Komputindo, Jakarta, 2011.

[12] Sutanta, Edhy, Sistem Informasi Manajemen, Graha Ilmu, Yogyakarta, 2003.

[13] Hirin A.M dan Virgi., Cepat Mahir Pemrograman Web dengan PHP dan MySQL, Prestasi Pustakaraya, Jakarta, 2011.
[14] Wahyono, Teguh., Practice Guide PHP On Windows, PT. Elex Media Komputindo, Jakarta, 2009.

[15] Taylor, PhD, David A., Object-Oriented Information System: Planning and Implementation, John Wiley \& Sons, Inc., Canada, 1992.

[16] Wicaksono, Diaz, Aplikasi Manajemen Praktikum Laboratorium Software Engineering Sistem Komputer Universitas Diponegoro, Skripsi S-1, Universitas Diponegoro, Semarang, 2014.

[17] Shodiq, Muchamad, Simbes, Aplikasi Manajemen Beasiswa di Universitas Diponegoro Berbasis Framework Code Igniter dan MySQL, Skripsi S-1, Universitas Diponegoro, Semarang, 2013. 